\title{
CORROSION ON POLISHED AND LASER-TEXTURED SURFACES OF AN Fe-Mn BIODEGRADABLE ALLOY
}

\author{
PRIMERJAVA KOROZIJSKIH LASTNOSTI POLIRANE IN \\ LASERSKO TEKSTURIRANE POVRŠINE BIORAZGRADLJIVE \\ ZLITINE Fe-Mn
}

\author{
Matej Hočevar ${ }^{1}$, Črtomir Donik ${ }^{1}$, Irena Paulin ${ }^{1}$, Aleksandra Kocijan ${ }^{1}$, \\ Franc Tehovnik ${ }^{1}$, Jaka Burja ${ }^{1}$, Peter Gregorčič ${ }^{2}$, Matjaž Godec ${ }^{1}$ \\ ${ }^{1}$ Institute of Metals and Technology, Lepi pot 11, 1000 Ljubljana, Slovenia \\ ${ }^{2}$ Faculty of Mechanical Engineering, University of Ljubljana, Aškerčeva 6, 1000 Ljubljana, Slovenia \\ matej.hocevar@imt.si \\ Prejem rokopisa - received: 2017-08-21; sprejem za objavo - accepted for publication: 2017-09-12
}

doi: $10.17222 /$ mit. 2017.140

\begin{abstract}
Fe-based biodegradable alloys such as Fe-Mn are interesting for biodegradable implants; however, their corrosion rate for such applications is too low. Here, nanosecond-laser surface texturing is applied as a successful surface treatment for increasing the degradation rate of an $\mathrm{Fe}-\mathrm{Mn}$ alloy. Laser texturing increases the surface area by increasing the surface porosity and generating a super-hydrophilic surface. Electrochemistry tests revealed that the laser-textured samples have a higher corrosion rate than a polished sample, thus enhancing the biodegradability of the Fe-Mn alloy. EDS analyses revealed a significantly higher content of $\mathrm{Mn}$ on the surface in the oxidized layer compared to the bulk Fe-Mn composition, which is one of the reasons for the increased corrosion rate. This work demonstrates the potential of laser-treated surfaces of biodegradable metals for biomedical applications.

Keywords: Fe-Mn alloy, laser texturing, corrosion, biodegradable, EDS analyses
\end{abstract}

Biološko razgradljive zlitine, kot so na primer Fe-Mn zlitine, so zanimive za uporabo v obliki biološko razgradljivih implantantov, vendar je njihova hitrost korozije za ciljne aplikacije še vedno prenizka. Lasersko teksturiranje površine predstavlja uspešno površinsko obdelavo za povečanje hitrosti razgradnje $\mathrm{Fe}-\mathrm{Mn}$ zlitine. Obdelava površine z laserjem poveča delež izpostavljene površine na račun večje poroznosti, obenem pa je novonastala površina superhidrofilna. Elektrokemijski testi so pokazali, da imajo vzorci, obdelani z laserjem, večjo stopnjo korozije v primerjavi s poliranimi vzorci, s čimer se poveča biorazgradljivost zlitine Fe-Mn. EDS analiza je pokazala povečano vsebnost Mn na površini v oksidirani plasti v primerjavi s kemijsko sestavo osnovnega materiala Fe-Mn, kar predstavlja eno od razlag za povečanje hitrosti korozije. Raziskava dokazuje potencial laserske obdelave površine biološko razgradljivih kovin za biomedicinske aplikacije.

Ključne besede: zlitina Fe-Mn, lasersko teksturiranje, korozija, biorazgradljivost, EDS analiza

\section{INTRODUCTION}

In recent years, biodegradable metals, such as $\mathrm{Fe}$ and $\mathrm{Mg}$ alloys, have emerged as a promising alternative in bone surgery, orthopaedic and cardiovascular applications. $^{1-4}$ The advantages of biodegradable metals are temporary support during tissue healing, progressive degradation, as well as reducing the long-term risks and side effects. ${ }^{1,2,5,6}$ Despite the high potential of these Fe-based materials, which possess similar mechanical properties to stainless steel, they exhibit one main weakness - the corrosion rate is too slow. ${ }^{6-8}$ However, with the addition of $\mathrm{Mn}$ as an alloying element, a trace element necessary in many enzymatic reactions, the corrosion rate is enhanced. ${ }^{2,9}$ Although the degradation is faster it is still too low, which represents a major problem for these recently developed Fe-Mn alloys. Another way to influence the corrosion rate of an Fe-Mn alloy without changing its chemical composition is to modify the surface morphology via mechanical treatments, including machining, sand blasting and laser surface modification. ${ }^{10-15}$ Increased surface areas, porous surfaces and surfaces with increased wettability (super-hydrophilic surfaces) have higher corrosion rates. ${ }^{11,16,17}$ However, not so many studies has been made on biodegradable Fe metals, and many of the existing treatments are usually applied to biocompatible materials with passivating surfaces such as AISI 316L stainless steel, titanium alloys, cobalt-chromium alloys and other similar alloys to improve the corrosion properties. ${ }^{11,18,19}$

The aim of the present study was to investigate the influence of a laser surface treatment on the corrosion behaviour of the Fe-Mn alloy due to changes in the surface properties. In contrast to other authors the content of $\mathrm{Mn}$ in our study was below $20 \%$ of mass fractions, with no additional changes in the chemical composition. Like the majority of the previous studies to simulate in-vivo conditions, the corrosion properties were investigated using Hank's solution. 
M. HOČEVAR et al.: CORROSION ON POLISHED AND LASER-TEXTURED SURFACES OF AN Fe-Mn ...

\section{EXPERIMENTAL PART}

\subsection{Material preparation}

An Fe-Mn alloy with $17 \%$ of mass fractions of Mn was produced from pure $\mathrm{Fe}$ with the addition of $\mathrm{Mn}$ to the alloy. The laboratory material was made in a $20 \mathrm{~kg}$ Leybold Heraeus vacuum induction furnace. The two 60 $\mathrm{mm} \times 60 \mathrm{~mm} \times 500 \mathrm{~mm}$ ingots of Fe-Mn alloy were cast and hot rolled to $60 \mathrm{~mm} \times 20 \mathrm{~mm} \times 150 \mathrm{~mm}$. The hot-rolled material was solution annealed at $1200{ }^{\circ} \mathrm{C}$ and quenched in oil. The chemical composition of the $\mathrm{Fe}-\mathrm{Mn}$ alloy was determined with an X-ray fluorescence spectrometer XRF (Thermo Scientific Niton XL3t GOLDD+) and a carbon and sulphur analyser (ELTRA CS-800). The chemical composition of produced Fe-Mn alloy in $\%$ of mass fractions of: $0.58 \% \mathrm{C}, 0.067 \% \mathrm{Si}$, $17.0 \% \mathrm{Mn}, 0.051 \% \mathrm{Cu}, 0.31 \% \mathrm{Mo}, 0.058 \% \mathrm{Ti}$, balance $\mathrm{Fe}$.

\subsection{Surface modification}

The Fe-Mn samples were cut into $15 \mathrm{~mm} \times 15 \mathrm{~mm}$ size squares and prepared by wet grinding down to 1200 grit followed by polishing down to $1 \mu \mathrm{m}$ with a diamond suspension to produce a smooth mirror finish. Selected samples were further textured by using a nanosecond laser (Nd:YAG) with a wavelength of $1064 \mathrm{~nm}$ and pulse duration of $95 \mathrm{~ns}$. The beam spot size was $0.05 \mathrm{~mm}$ and it was led in lines with a velocity of $1.6 \mathrm{~mm} / \mathrm{s}$ using a scanning head. The scan line separation equalled $50 \mu \mathrm{m}$. The texturing was performed with a pulse energy of $0.6 \mathrm{~mJ}$ and frequency of $1 \mathrm{kHz}$. Before laser texturing, the samples were cleaned with detergent, rinsed thoroughly with water and immersed in an ultrasonic bath in absolute ethanol for $12 \mathrm{~min}$.

\subsection{Electrochemical measurements}

Electrochemical measurements were performed on polished and laser-treated $\mathrm{Fe}-\mathrm{Mn}$ samples at room temperature in a simulated physiological Hank's solution, containing $8 \mathrm{~g} / \mathrm{L} \mathrm{NaCl}, 0.40 \mathrm{~g} / \mathrm{L} \mathrm{KCl}, 0.35 \mathrm{~g} / \mathrm{L}$ $\mathrm{NaHCO}_{3}, \quad 0.25 \mathrm{~g} / \mathrm{L} \quad \mathrm{NaH}_{2} \mathrm{PO}_{4}, 0.06 \mathrm{~g} / \mathrm{L} \quad \mathrm{Na}_{2} \mathrm{HPO}_{4}$, $0.19 \mathrm{~g} / \mathrm{L} \mathrm{CaCl}_{2}, 0.41 \mathrm{~g} / \mathrm{L} \mathrm{MgCl}_{2}, 0.06 \mathrm{~g} / \mathrm{L} \mathrm{Mg}_{\mathrm{s}} \mathrm{O}_{4}$ and $1 \mathrm{~g} / \mathrm{L}$ glucose, stabilized at $\mathrm{pH}=7.8$. All the chemicals were from Merck, Darmstadt, Germany. A three-elec- trode, flat BioLogic $\AA$ corrosion cell (volume $0.25 \mathrm{~L}$ ) was used for the corrosion measurements. The test specimen was employed as the working electrode (WE). The reference electrode (RE) was a saturated calomel electrode (SCE, 0.242 V vs. SHE) and the counter electrode (CE) was a platinum mesh. Electrochemical measurements were recorded using a BioLogic ${ }^{\circledR}$ Modular Research Grade Potentiostat/Galvanostat/FRA Model SP-300 with an EC-Lab® software V11.10. The specimens were immersed in the solution $1 \mathrm{~h}$ prior to the measurement in order to stabilize the surface at the open-circuit potential (OCP). The linear polarization measurements were performed at $\pm 25 \mathrm{mV}$ according to the OCP, using a scan rate of $0.01 \mathrm{mV} \mathrm{s}^{-1}$.

\subsection{Surface and metallographic investigation}

The surface morphologies of the polished and lasertextured samples were examined with a scanning electron microscope (SEM JEOL JSM-6500F) coupled with an energy-dispersive spectrometer (EDS INCA ENERGY 400) and a non-contact Alicona G4 3D optical Infinite-Focus Measuring (IFM) device. A cross-section of the laser-textured samples was studied using EDS line scan and EDS mapping analyses.

\section{RESULTS AND DISCUSSION}

\subsection{Surface characterization}

3D optical measurements (Figure 1) and SEM images (Figure 2) of the laser-modified sample reveal $100-\mu \mathrm{m}$-deep visible micro-channels, separated by $50 \mu \mathrm{m}$. The bimodal structure with a typical dimension of $10 \mu \mathrm{m}$ is formed at the top of these micro-channels due to laser ablation and melting. This nanostructured surface is covered by a Fe-Mn oxide layer (Figure $\mathbf{2 b}$ ). A 3D profile of the polished surface is shown in Figure 1b, where an ultra-smooth surface is visible with a surface roughness $S_{\mathrm{a}}<0.04 \mu \mathrm{m}$ compared to the lasertextured ultra-rough sample with $S_{\mathrm{a}}>25 \mu \mathrm{m}$. Additionally, the laser-textured sample exhibited super-hydrophilic behaviour after the treatment $\left(\theta=0^{\circ}\right)$, whereas the static contact angle on the polished surface is approaching the hydrophobic area $\left(\theta=70^{\circ}\right)$. As previously shown by other authors ${ }^{11,16,17}$ the increased surface roughness,

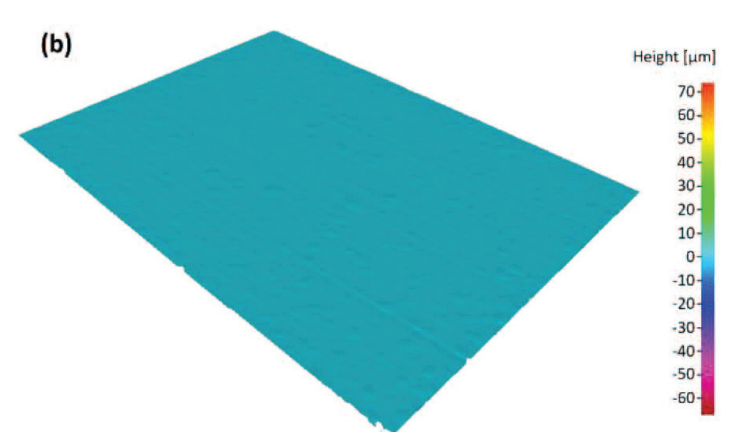

Figure 1: 3D height image representing the surface topography of a) laser-textured Fe-Mn sample and b) polished Fe-Mn sample 


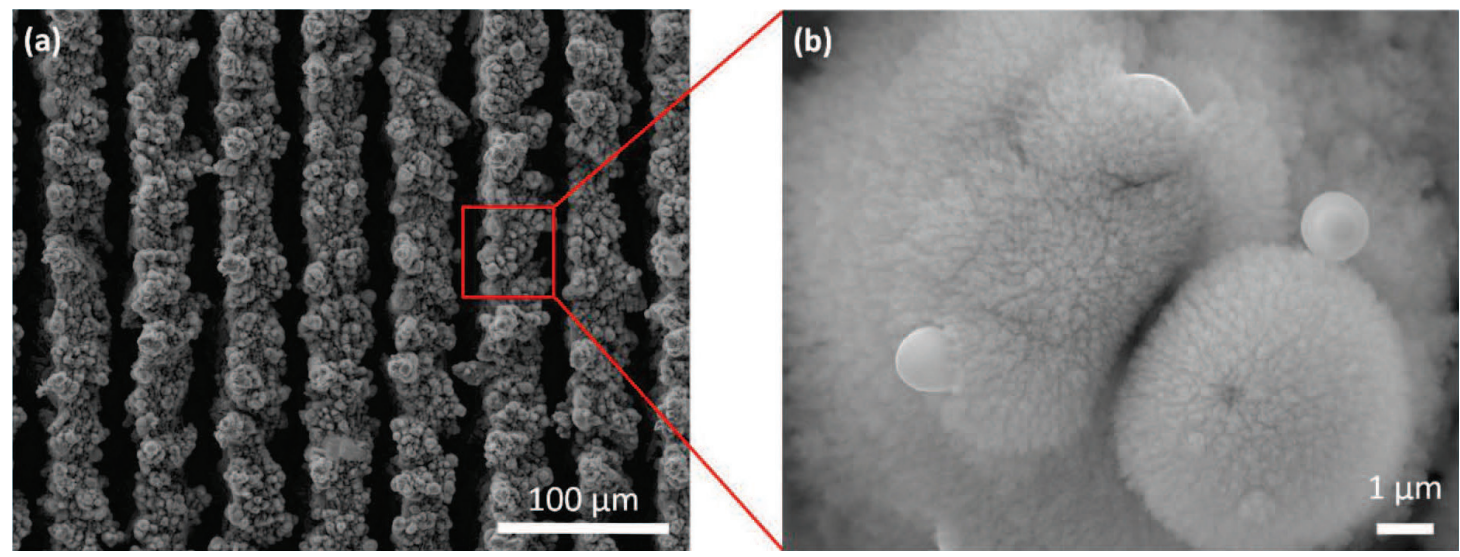

Figure 2: a) SEM image of surface topography of Fe-Mn laser-textured sample with micro-channels and b) highly magnified nanostructured surface covered by Fe-Mn oxide layer

porosity and also the super-hydrophilic behaviour of laser-treated $\mathrm{Fe}-\mathrm{Mn}$, significantly enhance the corrosion rate compared to the polished sample.

EDS analyses revealed a noticeable surface oxide layer. From the surface to the bulk the concentration of $\mathrm{O}$ is decreasing with increased Mn concentration (Figures 3 and 4). This is a known mechanism for increasing the corrosion rate. ${ }^{20}$ This increase of Mn causes depletion of
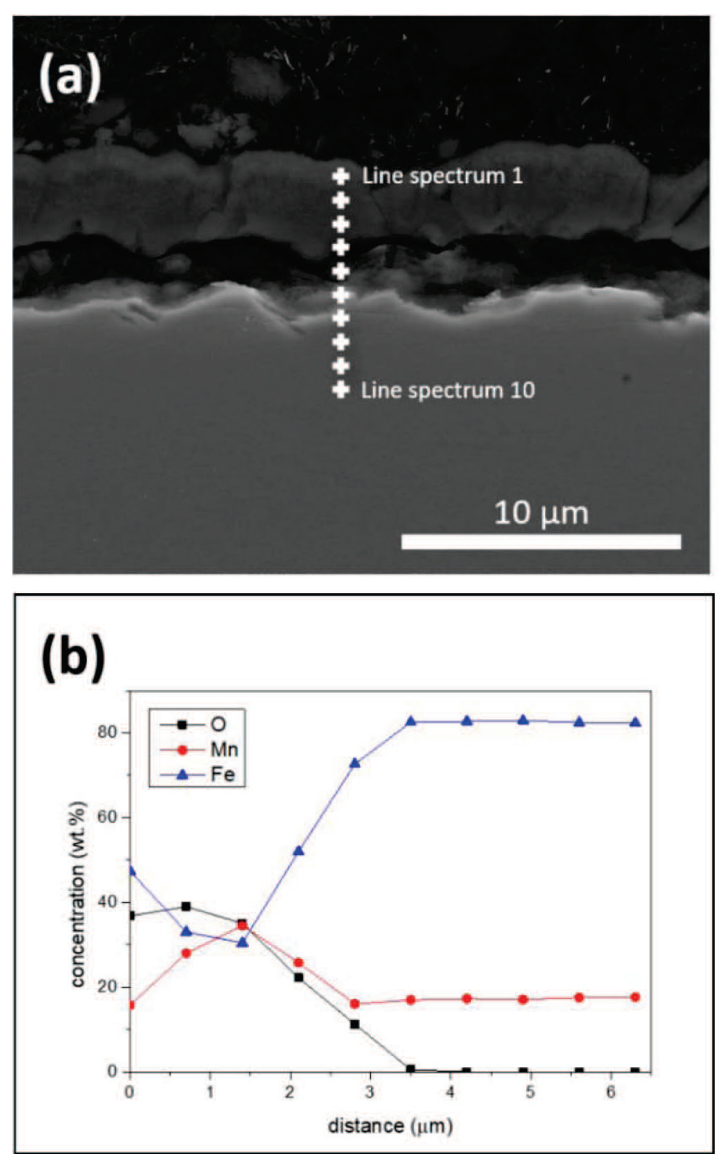

Figure 3: a) SEM cross-section image of laser-textured $\mathrm{Fe}-\mathrm{Mn}$ sample and b) the corresponding EDS line scan the $\mathrm{Fe}$ in the oxide layer and the ratio shifts to $\mathrm{Mn}>\mathrm{Fe}$ (Figures 3 and 4).

\subsection{Electrochemical measurements}

\subsubsection{Linear polarization}

Figure 5 shows the linear polarization curves for the polished and laser-textured $\mathrm{Fe}-\mathrm{Mn}$ samples in a simulated physiological Hank's solution at $\mathrm{pH}=7.8$. The calculations from the linear polarization measurements used the Equation (1):

$$
R_{\mathrm{p}}=\beta_{a} \beta_{c} /\left(2.3 I_{\text {corr }}\left(\beta_{a}+\beta_{c}\right)\right)
$$

The polarization resistance, $R_{\mathrm{p}}$, is evaluated from the linear polarization curves by applying a linear leastsquares fit of the data around OCP, $\pm 10 \mathrm{mV}$. The corrosion current, $I_{\text {corr }}$, is calculated from $R_{\mathrm{p}}$, the least-squares slope, and the Tafel constants, $\beta_{a}$ and $\beta_{c}$, of $120 \mathrm{mV}$ decade $^{-1}$. The value of $E_{(\mathrm{I}=0)}$ is calculated from the leastsquares intercept. The corrosion rates were calculated using the following conversion in Equation (2):
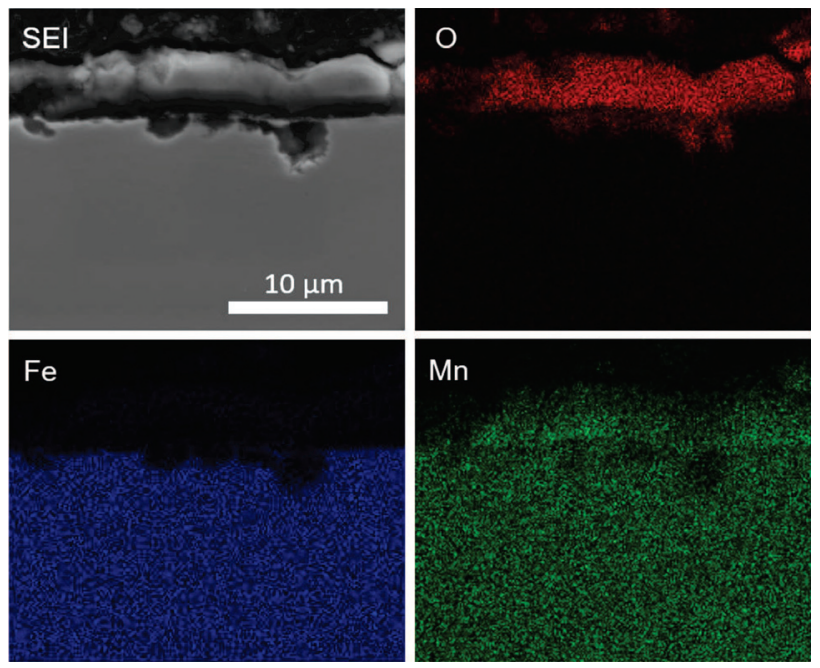

Figure 4: SEM cross-section image of laser-textured Fe-Mn sample and corresponding EDS elemental maps showing composition $(\mathrm{O}, \mathrm{Fe}$, $\mathrm{Mn})$ 


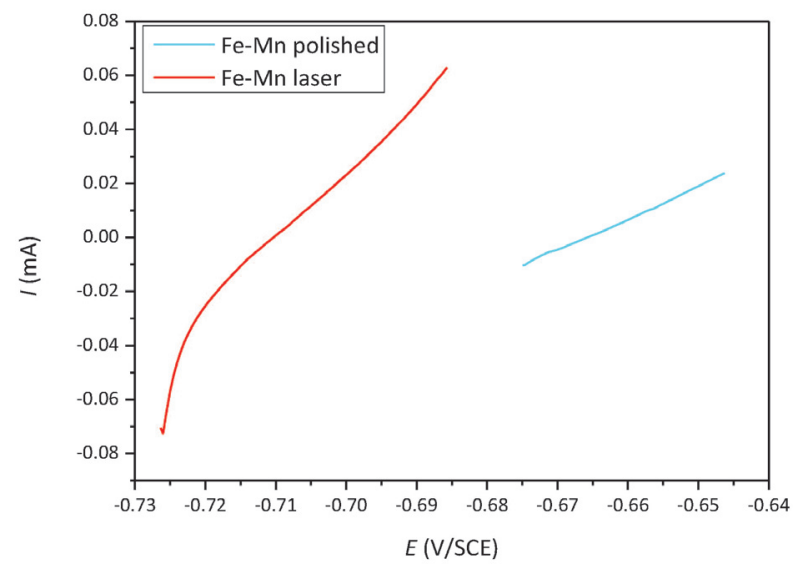

Figure 5: Linear polarization curve for polished and Fe-Mn lasertextured samples

$$
v_{\text {corr }}=C(E W / d)\left(I_{\text {corr }} / A\right),
$$

where $E W$ is the equivalent weight of the sample in $\mathrm{g}, A$ is the sample area in $\mathrm{cm}^{2}, d$ is its density in $\mathrm{g} / \mathrm{cm}^{3}$, and $C$ is a conversion constant that is dependent upon the required units. The results from the laser-treated $\mathrm{Fe}-\mathrm{Mn}$ demonstrate steeper linear polarization curves and therefore a lower corrosion resistance compared the other two samples of polished $\mathrm{Fe}-\mathrm{Mn}$ alloy, which have curves with similar inclines. The corrosion parameters calculated from the linear polarization with potentiodynamic measurement data in a simulated physiological Hank's solution indicated that the corrosion stability is higher for the polished $\mathrm{Fe}-\mathrm{Mn}$ than for the lasertextured surface. A higher corrosion rate indicates better biodegradability of laser-textured Fe-Mn sample. This was proven with the higher corrosion currents $\left(I_{\text {corr }}\right)$, higher corrosion rates $\left(v_{\text {corr }}\right)$ and lower polarization resistances $\left(R_{\mathrm{p}}\right)$, compared to the polished sample (Table 1). These results corroborate the results of earlier studies, ${ }^{21,22}$ where the corrosion rate is directly linked to the roughness and hydrophobicity.

Table 1: Corrosion characteristics of studied materials calculated from linear polarisation measurements

\begin{tabular}{|c|c|c|c|c|}
\hline & $I_{\text {corr }} / \mu \mathrm{A}$ & $E_{\text {corr }} / \mathrm{mV}$ & $\begin{array}{c}v_{\text {corr }} / \\
\text { nm year }^{-1}\end{array}$ & $R_{\mathrm{p}} / \mathrm{W}$ \\
\hline $\mathrm{Fe}-\mathrm{Mn}$ laser & 70.6 & -775 & 770 & 395 \\
\hline $\mathrm{Fe}-\mathrm{Mn}$ polished & 11.4 & -705 & 123 & 850 \\
\hline
\end{tabular}

\section{CONCLUSIONS}

Laser structuring using a nanosecond laser creates a super-hydrophilic surface with an increased exposed surface area containing nanostructured high-temperature oxides. In the present study, an electrochemical investigation confirmed that the laser treatment of the Fe-Mn alloy increases the corrosion rate by more than six times compared to the polished Fe-Mn alloy. The EDS line scan and the mapping showed a corrosion-favourable chemical composition changes, with Mn increasing and
Fe depleting in the exposed surface layer. The results in our study revealed that an increased exposed porous surface, super-hydrophobicity and Fe depletion in the oxide layer are the three main reasons leading to an increased biodegradability of the Fe-Mn alloy. We have shown that laser-surface texturing has a high potential for surface modification in biomedical applications, since the proposed approach might also be applicable to other biodegradable metals to increase the biodegradation.

\section{Acknowledgement}

The authors acknowledge the financial support from the Slovenian Research Agency (research core funding Nos. P2-0132 and P2-0392).

\section{REFERENCES}

${ }^{1}$ A. Francis, Y. Yang, S. Virtanen, A.R. Boccaccini, Iron and ironbased alloys for temporary cardiovascular applications, J. Mater. Sci. Mater. Med., 26 (2015), 138, doi:10.1007/s10856-015-5473-8

${ }^{2}$ H. Hermawan, Biodegradable Metals: From Concept to Applications, Springer, Berlin Heidelberg, 2012, doi:10.1007/978-3-642-31170-3

${ }^{3}$ J. Cheng, B. Liu, Y.H. Wu, Y.F. Zheng, Comparative in vitro Study on Pure Metals (Fe, Mn, Mg, Zn and W) as Biodegradable Metals, J. Mater. Sci. Technol., 29 (2013), 619-627, doi:10.1016/j.jmst. 2013.03.019

${ }^{4}$ H. Hermawan, D. Mantovani, Degradable metallic biomaterials: the concept, current developments and future directions, MINERVA Biotecnol., 21 (2009), 207-216

${ }^{1}$ L. Tan, X. Yu, P. Wan, K. Yang, Biodegradable Materials for Bone Repairs: A Review, J. Mater. Sci. Technol., 29 (2013), 503-513, doi:http://dx.doi.org/10.1016/j.jmst.2013.03.002

${ }^{5}$ M. P. Staiger, A. M. Pietak, J. Huadmai, G. Dias, Magnesium and its alloys as orthopedic biomaterials: A review, Biomaterials, 27 (2006), 1728-1734, doi:10.1016/j.biomaterials.2005.10.003

${ }^{6} \mathrm{Z}$. Zhen, T. XI, Y. Zheng, A review on in vitro corrosion performance test of biodegradable metallic materials, Trans. Nonferrous Met. Soc. China, 23 (2013), 2283-2293, doi:10.1016/S1003-6326(13)62730-2

${ }^{7}$ B. Liu, Y. F. Zheng, Effects of alloying elements (Mn, Co, Al, W, Sn, $\mathrm{B}, \mathrm{C}$ and $\mathrm{S}$ ) on biodegradability and in vitro biocompatibility of pure iron, Acta Biomater., 7 (2011), 1407-1420, doi:10.1016/j.actbio. 2010.11.001

${ }^{8}$ H. Hermawan, D. Dubé, D. Mantovani, Developments in metallic biodegradable stents, Acta Biomater., 6 (2010), 1693-1697, doi:10.1016/j.actbio.2009.10.006

${ }^{9}$ J. Zhou, Y. Yang, M. Alonso Frank, R. Detsch, A. R. Boccaccini, S. Virtanen, Accelerated Degradation Behavior and Cytocompatibility of Pure Iron Treated with Sandblasting, ACS Appl. Mater. $\{\&\}$ Interfaces, 8 (2016), 26482-26492, doi:10.1021/acsami.6b07068

${ }^{10}$ U. Trdan, M. Hočevar, P. Gregorčič, Transition from superhydrophilic to superhydrophobic state of laser textured stainless steel surface and its effect on corrosion resistance, Corros. Sci., (2017), doi:10.1016/j.corsci.2017.04.005

${ }^{11}$ L. De Lara, R. Jagdheesh, J. L. Ocana, Corrosion resistance of laser patterned ultrahydrophobic aluminium surface, Mater. Lett., 184 (2016), 100-103, doi:10.1016/j.matlet.2016.08.022

${ }^{12}$ M. S. Brown, C. B. Arnold, Fundamentals of Laser-Material Interaction and Application to Multiscale Surface Modification, in: K. Sugioka, M. Meunier, A. Piqué (Eds.), Laser Precis. Microfabr., Springer Berlin Heidelberg, Berlin, Heidelberg, 2010: 91-120, doi:10.1007/978-3-642-10523-4_4 


\section{MATERIALI IN TEHNOLOGIJE/MATERIALS AND TECHNOLOGY (1967-2017) - 50 LET/50 YEARS}

\section{HOČEVAR et al.: CORROSION ON POLISHED AND LASER-TEXTURED SURFACES OF AN Fe-Mn ...}

${ }^{13}$ M. Svantner, M. Kucera, S. Houdkova, J. Riha, Influence of laser ablation on stainless steel corrosion behaviour, in: Met. $201120 \mathrm{TH}$ Anniv. Int. Conf. Metall. Mater., Tanger LTD, Keltickova 62, Slezska, Ostrava 710 00, Czech Republic, 2011: 752-757

${ }^{14}$ A. Kocijan, I. Paulin, C. Donik, M. Hocevar, K. Zelic, M. Godec, Influence of Different Production Processes on the Biodegradability of an FeMn17 Alloy, Mater. Tehnol., 50 (2016), 805-811, doi:10.17222/mit.2016.055

${ }^{15}$ G. Ryan, A. Pandit, D. P. Apatsidis, Fabrication methods of porous metals for use in orthopaedic applications, Biomaterials, 27 (2006), 2651-2670, doi:10.1016/j.biomaterials.2005.12.002

${ }^{16}$ Z. Zhen, T. Xi, Y. Zheng, A review on in vitro corrosion performance test of biodegradable metallic materials, Trans. Nonferrous Met. Soc. China, 23 (2013), 2283-2293, doi:10.1016/S1003-6326(13)62730-2

${ }^{17}$ Y. F. Zheng, X. N. Gu, F. Witte, Biodegradable metals, Mater. Sci. Eng. R Reports, 77 (2014), 1-34, doi:10.1016/j.mser.2014.01.001
${ }^{18}$ M. T. Mohammed, Z. A. Khan, A. N. Siddiquee, Surface Modifications of Titanium Materials for developing Corrosion Behavior in Human Body Environment: A Review, Procedia Mater. Sci., 6 (2014), 1610-1618, doi:10.1016/j.mspro.2014.07.144

${ }^{19}$ A. Kawashima, K. Asami, K. Hashimoto, Effect of Manganese on The Corrosion Behavior of Chromium-Bearing Amorphous Metal-Metalloid Alloys, Sci. Reports Res. Institutes Tohoku Univ. Ser. A-PHYSICS Chem. Metall., 29 (1981), 276-283

${ }^{20}$ J. E. Tang, M. Halvarsson, H. Asteman, J. E. Svensson, Microstructure of oxidised 304L steel and the effects of surface roughness on oxidation behaviour, in: R.W.I.G.K.R.C.C.M.G.A. Streiff (Ed.), 2001: 205-214

${ }^{21}$ A. Dunn, K. L. Wlodarczyk, J. V Carstensen, E. B. Hansen, J. Gabzdyl, P. M. Harrison, J. D. Shephard, D. P. Hand, Laser surface texturing for high friction contacts, Appl. Surf. Sci., 357 (2015), 2313-2319, doi:10.1016/j.apsusc.2015.09.233 